\title{
Karakteristik Metadata Pada Sharing File Di Media Sosial Untuk Mendukung Analisis Bukti Digital
}

\author{
Dimas Pamilih Epin Andrian ${ }^{1 *}$, Dhomas Hatta Fudholi ${ }^{2)}$, Yudi Prayudi ${ }^{3)}$ \\ 1,2,3) Teknik Informatika Fakultas Teknologi Industri, Universitas Islam Indonesia Yogyakarta \\ 1)15917207@students.uii.ac.id, ${ }^{2)}$ hatta.fudholi@uii.ac.id, ${ }^{3)}$ prayudi@uii.ac.id
}

\begin{abstract}
Metadata is information in a file which its contents are an explanation of the file. Metadata contains information about the contents of data for file management purposes. In various cases involving digital evidence, investigators can uncover a case through the metadata file. Problems that arise when file metadata has changed or deleted information, for example, the moment that a file is shared via social media. Basically, all of the shared files through social media will experience changes in metadata information. This study conducted detailed analysis of changes in metadata information and hex dump values to determine the changing characteristics of metadata files shared in social media. This research method applied a comparison table to see the details of changes in metadata values from all files and social media as research objects. The results of this study are expected to have contribution for forensic analysts to identify the shared metadata characteristics of files in social media. As a result, later, the source of shared files in social media will be known. Moreover, it is expected from these findings that forensic analysts can explore the social media used by the cybercrime perpetrators.
\end{abstract}

\section{Keywords : Metadata, Hex Dump, Social Media}

\section{PENDAHULUAN}

Seiring berkembangnya teknologi informasi, secara tidak langsung berbanding lurus dengan perkembangan kejahatan di dunia teknologi informasi atau kejahatan dunia maya (cyber crime). Perkembangan ini diikuti dengan munculnya berbagai macam perangkat digital terbaru, yang lebih cepat dalam menyampaikan informasi, mobilitas tinggi dengan mudah dapat diakses dimanapun dan kapanpun. Hal ini menyebabkan banyak munculnya berbagai dokumen digital yang bermacam-macam format/ekstensi filenya.

Berdasarkan Undang-Undang Republik Indonesia Nomor 11 Tahun 2008 tentang Informasi dan Transaksi Elektronik pasal 5 ayat 1 : “ Informasi Elektronik dan/atau Dokumen Elektronik dan/atau hasil cetaknya merupakan alat bukti hukum yang sah ", maka peran forensik digital untuk membuktikan suatu kasus kejahatan digital menjadi sangat dibutuhkan.

Kasus yang pernah disidangkan di Pengadilan Negeri Yogyakarta pada Kamis, 13 Juli 2017 jam 13.00-17.00 WIB dengan Nomor Perkara : 184/pid.Sus/2017/PN Yyk, Jenis Perkara : Informasi dan Transaksi Elektronik (Kasus HOAX Sultan HB X Yogyakarta), Terdakwa : Rosyid Nur Rohim dan Agenda : Pemeriksaan Saksi. Penyelidikan dilakukan dan ditemukan barang bukti elektronik yakni laptop dan modem. Dari laptop terdakwa ditemukan file gambar yang digunakan untuk memuat berita, tetapi penyidik belum menemukan sumber gambar tersebut. Akhirnya dengan metode internet forensik ditemukan sumber gambar tersebut yakni berasal dari media sosial facebook.

Dalam berbagai kasus yang melibatkan barang bukti digital, penyidik dapat mengungkap kasus salah satunya melalui informasi mengenai isi dari sebuah file digital yang disebut dengan metadata file. Metadata merupakan informasi yang ditanam pada sebuah file yang isinya berupa penjelasan tentang file tersebut. Metadata mengandung informasi mengenai isi dari suatu data yang dipakai untuk keperluan manajemen file atau data itu nantinya dalam suatu basis data. Metadata sering disebut " informasi tentang informasi " atau "data tentang data " (Riley, 2017). 
Permasalahan yang diangkat dalam penelitian ini adalah bagaimana menentukan sumber media sosial yang digunakan untuk membagikan file digital dan keaslian file yang telah dibagikan lewat media sosial dengan mencari perubahan karakteristik metadata pada file tersebut. Pada dasarnya semua file yang di sharing lewat media sosial pasti mengalami perubahan metadata pada file tersebut, maka dari itu penelitian ini ingin mengecek detail metadata dan nilai hex dump yang berubah apa saja.

Tujuan dari penelitian ini untuk memahami dan membaca karakteristik metadata file sebelum dan sesudah dibagikan di media sosial sehingga diharapkan dapat membantu dan memberikan konstribusi pada analis forensik dalam mengenali metadata file yang telah dibagikan lewat media sosial atau dapat menentukan sumber media sosial yang digunakan untuk membagikan file dan menentukan keaslian file tersebut apakah dapat digunakan sebagai barang bukti dipersidangan. Kemudian dari temuan tersebut diharapkan analis forensik dapat mendalami kasus melalui media sosial yang digunakan pelaku cyber crime seperti untuk profiling dan tracking.

Media sosial yang akan digunakan dalam penelitian ini merupakan media sosial yang dapat melakukan sharing file DOCX, PDF, JPG, MP3 dan MP4. Berdasarkan survey Hootsuite, (2020) platform media sosial paling aktif di Indonesia adalah Youtube $88 \%$, Whatsapp 84\%, Facebook 82\% dan Instagram 79\% dapat dilihat pada Gambar 1.

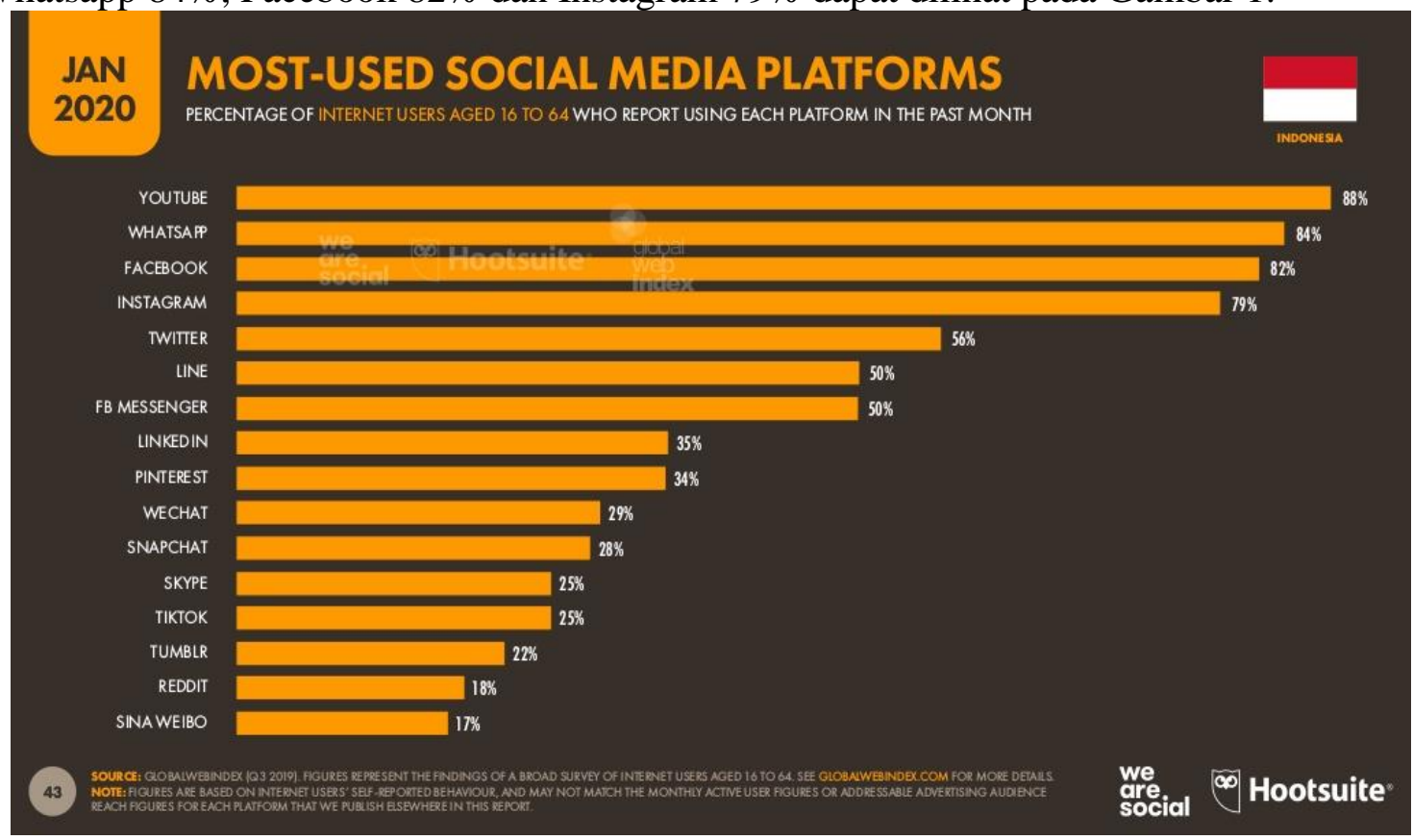

Gambar 1. Platform media sosial yang paling aktif di Indonesia

\section{TINJAUAN PUSTAKA}

Penelitian yang dilakukan oleh Alanazi \& Jones, (2016) mengatakan bagaimana menggunakan berbagai format dan jenis metadata untuk memvalidasi berbagai jenis dokumen dan file yang memiliki sejumlah format dan jenis metadata yang dapat digunakan untuk menemukan properti dari file, dokumen atau aktivitas sebuah jaringan. Selain itu, metadata banyak digunakan di kondisi apapun, dimana metadata dapat memberikan beragam bukti antara sekelompok orang, karena sebagian diantaranya tidak mengetahui jenis informasi yang tersimpan dalam dokumen mereka.

Penelitian yang dilakukan oleh Spore, (2016) mengatakan tujuan pemeriksaan forensik terhadap metadata yaitu mengaitkan data dengan informasi lain, pengguna yang mengaksesnya, direktori file tempat penyimpanannya, terakhir kali di-copy, dan sebagainya. Dalam sebuah kasus metadata dapat menghasilkan bukti tidak langsung untuk 
mendukung barang bukti. Anda bisa melihat bagaimana file diakses, sesuai urutan dan oleh siapa. Hampir semua tindakan yang Anda lakukan dengan sebuah file mengubah beberapa aspek metadatanya. Dengan analisis forensik yang tepat, metadata dapat membantu menyoroti pola, menetapkan timelines dan menunjukkan kesenjangan dalam data.

Dalam penelitiannya Kumar et al., (2016) mengatakan suatu hari secara langsung dan tidak langsung sudah banyak sekali perangkat pintar yang melekat pada seseorang. Seseorang dapat menemukan keberadaannya jika kita memantau perangkat yang mereka gunakan dengan mengumpulkan metadata foto yang diposkan oleh mereka di media sosial. Beberapa situs media sosial memiliki fitur untuk memposting tempat masa lalu mereka. Untuk menyediakan aplikasi Android sederhana ini menggunakan fitur Geo Tagging yang tersedia di sebagian besar perangkat pintar. Dengan menggunakan data berbasis lokasi ini bisa melacak orang berdasarkan garis bujur dan garis lintang dari Global Positioning System (GPS). Langkah ini bisa digunakan untuk mengumpulkan foto yang diposkan oleh seseorang dan menganalisanya untuk mengetahui posisi mereka saat ini. Memverifikasi metadata yang terkait dengan gambar dan melacak di suatu negara, kota, rute dan jalan negara berdasarkan ketinggian GPS, GPS Latitude, GPS Bujur dan posisi GPS.

Dalam penelitiannya Subli et al., (2017) penelitiannya membahas cara lain proses investigasi dengan melakukan pendekatan metadata untuk melihat langsung metadata file secara umum dan menemukan file berdasarkan korelasi file dengan parameter dari file yang telah ditentukan.

Penelitian berikutnya dilanjutkan oleh Zaenudin et al., (2018) dalam penelitiannya membuat sistem dari pendekatan berbasis metadata untuk memahami dan membaca karakteristik metadata secara umum dan untuk menentukan korelasi antara artefak.

Penelitian berikutnya oleh Putra et al., (2018) membahas konsep dasar dalam melakukan analisis deteksi video dengan membuat sample video editing, dimana sample video editing digunakan untuk membandingkan metadata rekaman video asli dan kemudian selanjutnya tahap Processing Exiftool, dimana tahap ini adalah proses membaca metadata video dengan exiftool dan tahap akhir adalah analisa hasil metadata perbedaan dari video asli dengan video editing.

Penelitian yang dilakukan oleh Khatri, (2019) membahas mengenai ekstraksi metadata menggunakan Spotlight dari OSX Apple yang memungkinkan pengguna untuk mencari bukan hanya file saja, tetapi juga mengirimkan arsip, alamat, kontak atau aset digital lainnya yang tertanam dalam file. Mengumpulkan lebih banyak data tentang file, seperti waktu terakhir dibuka, jumlah yang digunakan, waktu dan tanggal penggunaan.

\section{METODE PENELITIAN}

Metode penelitian di bangun secara garis besar menjadi tiga tahapan yang dapat dilihat pada Gambar 2. Tahapan awal dimulai dari identifikasi masalah dan tinjauan pustaka. Tahap kedua tahapan proses dan analisis dimulai dari pengumpulan data, proses sharing, membaca metadata dan nilai hex dump, analisis hasil dari membaca metadata. Tahapan akhir membuat kesimpulan dengan membuat laporan penelitian.

Pengumpulan data dengan cara membuat beberapa sampel file yang akan dijadikan variabel atau objek penelitian yakni docx, pdf, jpg, mp3 dan mp4. Kemudian file tersebut dibagikan melalui media sosial seperti youtube (khusus file mp4), whatsapp (file mp4,jpg, mp3, pdf, dan docx), facebook (file mp4 dan jpg) dan instagram (file mp4 dan jpg). File asli dan file sharing dilakukan analisis perubahan informasi dengan cara melihat, membaca dan membandingkan nilai metadata dan nilai hex dump dari semua file untuk mengetahui perubahan yang memiliki nilai perubahan konsisten di setiap media sosial. Dari perubahan inilah yang menjadi karakteristik metadata pada sharing file yang di bagikan lewat media sosial. 
Tahapan akhir akan memberikan informasi berkaitan dengan masalah dalam penelitian yakni karakteristik perubahan metadata untuk setiap file dan setiap media sosial yang dapat dijadikan gambaran untuk menentukan sumber media sosial yang digunakan untuk membagikan file tersebut. Kemudian menentukan keaslian file apabila tidak terdapat perubahan metadata pada file yang telah dibagikan di media sosial.

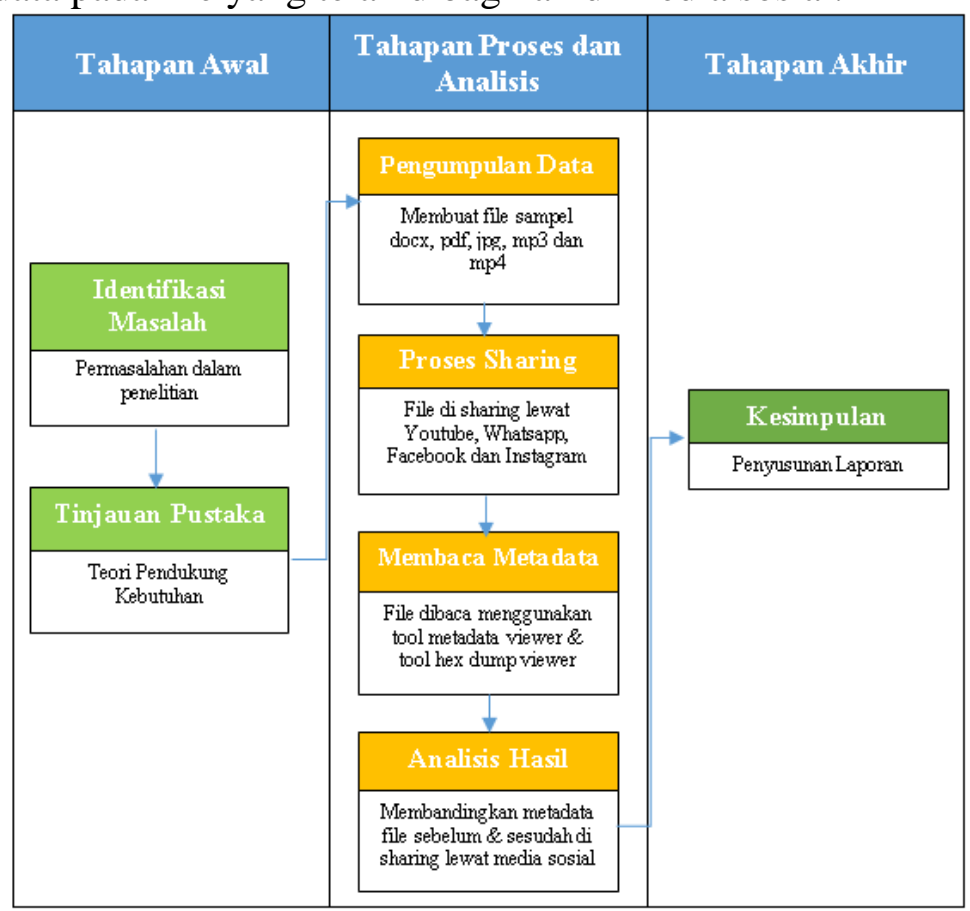

Gambar 2. Metode Penelitian Karakteristik Metadata File Sharing Di Media Sosial

\section{HASIL DAN PEMBAHASAN}

Tahap awal dalam penelitian dimulai dengan membuat file asli untuk setiap jenis ekstensinya, yaitu 5 file ekstensi docx, 5 file ekstensi pdf, 5 file ekstensi jpg, 5 file ekstensi mp3 dan 5 file ekstensi mp4 dengan total file asli berjumlah 25 file.

File format docx dan pdf dibuat menggunakan lima aplikasi word editor yang berbeda yaitu google docs, libreoffice, ms. word 2019, ms. word online (office live) dan wps office 2019. File jpg dan mp4 dibuat menggunakan lima kamera ponsel yang berbeda merk yaitu Sony Xperia, Sony Ericson, Samsung, Nokia Asha dan Haier Andromax. Sedangkan file mp3 dibuat menggunakan aplikasi Sound Recorder dan hasil rekaman dari ponsel dalam format amr kemudian dikonvert menggunakan aplikasi amr to mp3. Alur membaca metadata dan nilai hex dump setiap file dapat dilihat pada Gambar 3. 


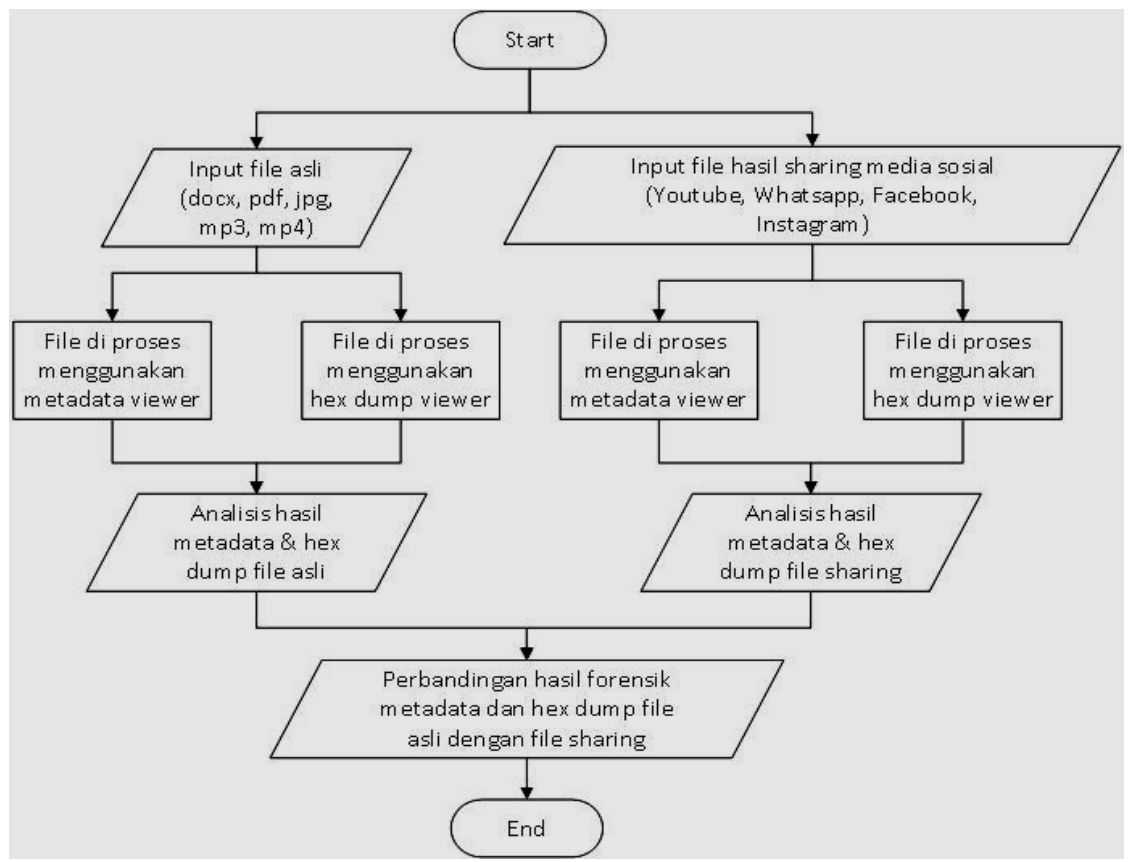

Gambar 3. Alur sistem metadata viewer

Untuk membaca metadata pada file, menggunakan get-metadata yang dapat diakses online pada alamat url https://www.metadata2go.com/ karena dapat membaca seluruh metadata dari berbagai macam format file. Sedangkan untuk membaca nilai hex dump, menggunakan aplikasi Hex Editor Neo.

Penjelasan alur sistem metadata viewer pada Gambar 3 sebagai berikut :

1. Langkah pertama, membaca seluruh metadata dan nilai hex dump dari semua file asli yang belum dibagikan melalui media sosial, kemudian membuat tabel metadata dan nilai hex dump untuk file asli sesuai dengan ekstensi filenya.

2. Semua file asli dibagikan dan diunduh melalui media sosial yang telah ditentukan yaitu Youtube untuk file berekstensi mp4; WhatsApp untuk file berekstensi mp4, mp3, jpg, docx dan pdf; Facebook untuk file berekstensi mp4 dan jpg; Dan Instagram untuk file berekstensi mp4 dan jpg. Semua file hasil unduhan atau file sharing dilakukan pembacaan metadata dan nilai hex dump, kemudian membuat tabel untuk metadata dan nilai hex dump untuk file sharing sesuai dengan ekstensi file dan jenis media sosialnya.

3. Hasil membuat tabel metadata dan nilai hex dump dari file asli dan dari file sharing, kemudian dilakukan perbandingan dari dua tabel tersebut untuk mencari perubahan pada metadata dan nilai hex dump dari setiap ekstensi file dan dari setiap jenis media sosialnya.

4. Nilai metadata dan nilai hex dump yang mengalami perubahan ditandai dengan membuat 4 kelompok perubahan yaitu penambahan jenis metadata; pengurangan atau penghapusan jenis metadata; perubahan pada nilai metadata; dan pengurangan atau penghapusan nilai metadata.

5. Hasil kelompok perubahan nilai metadata dan nilai hex dump digunakan untuk mencari nilai metadata yang mengalami perubahan tetap atau sama pada setiap ekstensi file dan jenis media sosial yang digunakan untuk sharing file.

6. Nilai metadata yang mengalami perubahan tetap dan sama inilah yang menjadi karakteristik utama dalam penelitian ini untuk mengetahui atau menentukan sumber penyebaran file dari media sosial yang dijadikan objek penelitian.

Hasil perubahan metadata yang menjadi karakteristik utama dari metadata file sharing dapat dijelaskan sebagai berikut : 


\section{Media Sosial YouTube}

Youtube sendiri hanya dapat digunakan untuk berbagi file video seperti format MP4. Perubahan yang menjadi karakteristik utama pada file video youtube terletak pada metadata bernama Compatiblebrands Handler Description dengan nilai : ISO Media file produced by Google Inc. Setiap file video yang diunduh melalui media sosial Youtube selalu memiliki metadata dengan nilai tersebut. Tabel 1 menampilkan 4 dari 84 jenis metadata yang menjadi karakteristik perubahan metadata yang diuji pada file sampel sebanyak 5 kali.

Tabel 1. Karakteristik Perubahan Metadata File Sharing Mp4 via Youtube

\begin{tabular}{|c|l|l|l|}
\hline No & \multicolumn{1}{|c|}{ Nama Metadata } & \multicolumn{1}{|c|}{ Nilai Metadata file Asli } & \multicolumn{1}{|c|}{ Nilai Metadata file Sharing } \\
\hline 1. & $\begin{array}{l}\text { Compatiblebrands } \\
\text { Media Time Scale }\end{array}$ & 48000 & 44100 \\
\hline 2. & $\begin{array}{l}\text { Compatiblebrands } \\
\text { Handler Description }\end{array}$ & SoundHandle & $\begin{array}{l}\text { ISO Media file produced by Google } \\
\text { Inc }\end{array}$ \\
\hline 3. & $\begin{array}{l}\text { Compatiblebrands Audio } \\
\text { Sample Rate }\end{array}$ & 48000 & 44100 \\
\hline 4. & $\begin{array}{l}\text { Compatiblebrands } \\
\text { Rotation }\end{array}$ & 90 & 0 \\
\hline
\end{tabular}

\begin{tabular}{|l|}
\hline Media Create Date \\
\hline Media Modify Date \\
\hline Media Time Scale \\
\hline Media Duration \\
\hline Handler Type \\
\hline Handler Description \\
\hline Balance \\
\hline Audio Format \\
\hline Audio Channels \\
\hline Audio Bits Per Sample \\
\hline Audio Sample Rate \\
\hline Movie Data Size \\
\hline Movie Data Offset \\
\hline Avg Bitrate \\
\hline Image Size \\
\hline Megapixels \\
\hline Rotation \\
\hline Category \\
\hline
\end{tabular}

(a) file asli

\begin{tabular}{l}
\hline 2019:08:12 06:46:56 \\
\hline $2019: 08: 1206: 46: 56$ \\
\hline 48000 \\
$20.42 \mathrm{~s}$ \\
\hline Audio Track \\
\hline SoundHandle \\
\hline 0 \\
\hline mp4a \\
\hline 2 \\
\hline 16 \\
\hline 48000 \\
\hline 45055807 \\
\hline 810040 \\
\hline 17.6 Mbps \\
\hline $1920 \times 1080$ \\
\hline 2.1 \\
\hline 90 \\
\hline video \\
\hline
\end{tabular}

Gambar 4. Perubahan Metadata File Mp4 Di Youtube

\begin{tabular}{|l|}
\hline Media Create Date \\
\hline Media Modify Date \\
\hline Media Time Scale \\
\hline Media Duration \\
\hline Media Language Code \\
\hline Handler Type \\
\hline Handler Description \\
\hline Audio Format \\
\hline Audio Channels \\
\hline Audio Bits Per Sample \\
\hline Audio Sample Rate \\
\hline Balance \\
\hline Avg Bitrate \\
\hline Image Size \\
\hline Megapixels \\
\hline Rotation \\
\hline Category \\
\hline
\end{tabular}

\begin{tabular}{l} 
2019:10:27 21:33:42 \\
2019:10:27 21:33:42 \\
44100 \\
$20.50 \mathrm{~s}$ \\
eng \\
Audio Track \\
150 Media file produced by Google Inc. \\
mp4a \\
\hline 2 \\
16 \\
44100 \\
0 \\
$1.13 \mathrm{Mbps}$ \\
$608 \times 1080$ \\
0.657 \\
0 \\
video
\end{tabular}

(b) file sharing

\section{Media Sosial WhatsApp}

WhatsApp dapat digunakan untuk berbagi file mulai dari video, gambar, audio sampai dokumen. Perubahan yang menjadi karakteristik utama untuk file video terletak pada nilai raw header hex dump, karena hampir keseluruhan metadata tidak mengalami perubahan nilai. Ada dua raw header yang dapat ditemukan. Tabel 2 menampilkan 2 dari 84 jenis metadata yang menjadi karakteristik perubahan metadata yang diuji pada file sampel sebanyak 5 kali.

Tabel 2. Karakteristik Perubahan Metadata File Sharing Mp4 via Whatsapp

\begin{tabular}{|c|c|c|c|}
\hline No & $\begin{array}{c}\text { Nama } \\
\text { Metadata }\end{array}$ & Nilai Metadata file Asli & Nilai Metadata file Sharing \\
\hline 1. & $\begin{array}{l}\text { Raw } \\
\text { Header Hex } \\
\text { Dump }\end{array}$ & $\begin{array}{l}00000018667479706 d 703432 \\
00000000 \\
69736 f 6 d 6 d 7034320000279 a 6 d \\
6 f 6 f 76 \\
0000006 c 6 d 76686400000000 \\
d 68 e 07 d 9 \\
\text { d6 8e } 07 \text { d9 } 000003 \text { e8 } 00007 c 9500 \\
010000\end{array}$ & 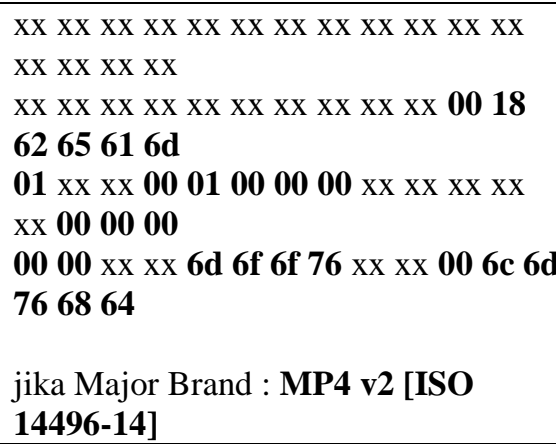 \\
\hline
\end{tabular}




\begin{tabular}{|c|c|c|c|}
\hline No & $\begin{array}{c}\text { Nama } \\
\text { Metadata }\end{array}$ & Nilai Metadata file Asli & Nilai Metadata file Sharing \\
\hline 2. & $\begin{array}{l}\text { Raw } \\
\text { Header Hex } \\
\text { Dump }\end{array}$ & $\begin{array}{l}00000020667479706973 \text { 6f 6d } 00 \\
000200 \\
69736 f 6 d 6973 \text { 6f } 3261766331 \text { 6d } \\
703431 \\
000018 \text { a 6d 6f 6f } 76000000 \text { 6c 6d } \\
766864 \\
00000000 \text { d6 8e } 07 d 9 \text { d6 8e } 07 d 900 \\
0003 \text { e }\end{array}$ & 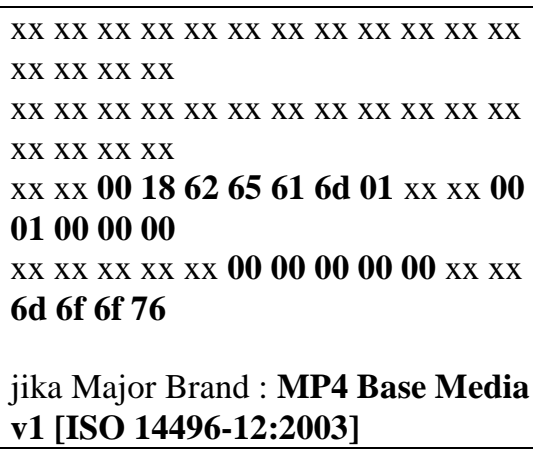 \\
\hline
\end{tabular}

Nilai cetak tebal pada kolom nilai metadata file sharing diatas adalah perubahan yang memiliki nilai tetap dan sama ketika file video diunduh melalui WhatsApp. Dari kedua raw header diatas, sebenarnya memiliki nilai urutan yang sama karena dari media sosial yang sama, akan tetapi posisi nilainya saja yang bergeser atau berbeda tempat.

\begin{tabular}{|c|c|c|c|c|c|c|c|c|c|c|c|c|c|c|c|c|c|}
\hline & 00 & 01 & 02 & 03 & 4 & 0.5 & 06 & 07 & 08 & 09 & $0 \mathrm{a}$ & $\mathrm{Ob}$ & $0 \mathrm{c}$ & $0 \mathrm{~d}$ & De & of & \\
\hline & 00 & 00 & 00 & 18 & 66 & 74 & 79 & 70 & $6 \mathrm{~d}$ & 70 & 34 & 32 & 00 & 00 & 00 & 00 & \\
\hline 0000 & 69 & 73 & $6 f$ & $6 \mathrm{~d}$ & $6 \mathrm{~d}$ & 70 & 34 & 32 & 00 & 00 & 27 & $9 \mathrm{a}$ & $6 \mathrm{~d}$ & $6 f$ & $6 f$ & 76 & isominp $42 .$. ' šmoov \\
\hline 00000020 & 00 & 00 & 00 & 60 & $6 \mathrm{~d}$ & 76 & 68 & $64 \div 2$ & 00 & 00 & 00 & 00 & d6 & $8 \mathrm{e}$ & 07 & d9 & hd. . . .öž. Ù \\
\hline 00000030 & $d 6$ & $8 \mathrm{e}$ & 07 & d 9 & 00 & 00 & 03 & e8 & 00 & 00 & $7 \mathrm{c}$ & 95 & 00 & 01 & 00 & 00 & تِ \\
\hline
\end{tabular}

(a) file asli

\begin{tabular}{|c|c|c|c|c|c|c|c|c|c|c|c|c|c|c|c|c|c|}
\hline & 00 & 01 & 02 & 03 & 04 & 05 & 06 & 07 & 08 & 09 & $0 \mathrm{a}$ & $\mathrm{Ob}$ & $0 \mathrm{c}$ & $0 d$ & De & of & \\
\hline 00000000 & 00 & 00 & 00 & 18 & 66 & 74 & 79 & 70 & $6 \mathrm{~d}$ & 70 & 34 & 32 & 00 & 00 & 00 & 00 & $42 .$. \\
\hline 00000010 & 69 & 73 & $6 f$ & $6 \mathrm{~d}$ & $6 \mathrm{~d}$ & 70 & 34 & 32 & 00 & 00 & 00 & 18 & 62 & 65 & 61 & $6 \mathrm{~d}$ & isomin $42 . .$. beam \\
\hline 00000020 & 01 & 00 & 00 & 00 & 01 & 00 & 00 & 00 & 00 & 00 & 00 & 00 & 07 & 00 & 00 & 00 & . \\
\hline 00000030 & 00 & 00 & 27 & $9 a$ & $6 \mathrm{~d}$ & $6 f$ & $6 f$ & 76 & 00 & 00 & 00 & $6 \mathrm{c}$ & $6 \mathrm{~d}$ & 76 & 68 & 64 & .. 'šmoov... . limvhd \\
\hline
\end{tabular}

(b) file sharing

Gambar 5. Perubahan Raw Header Hex Dump File Mp4 Di WhatsApp dengan Major Brand MP4 v2 [ISO 14496-14]

\begin{tabular}{|c|c|c|c|c|c|c|c|c|c|c|c|c|c|c|c|c|c|}
\hline & \multirow[b]{2}{*}{00} & \multirow[b]{2}{*}{01} & \multirow{2}{*}{\multicolumn{2}{|c|}{$02 \quad 03$}} & \multirow{2}{*}{\multicolumn{2}{|c|}{0405}} & \multirow{2}{*}{\multicolumn{2}{|c|}{$06 \quad 07$}} & \multirow{2}{*}{\multicolumn{3}{|c|}{$08 \quad 09 \quad 08$}} & & \\
\hline & & & & & & & & & & & & $\mathrm{Ob}$ & $0 \mathrm{c}$ & Od & oe & of & \\
\hline 00000000 & 00 & 00 & 00 & 20 & 66 & 74 & 79 & 70 & 69 & 73 & $6 \mathrm{f}$ & $6 \mathrm{~d}$ & 00 & 00 & 02 & 00 & ... ftypisom.... \\
\hline 00000010 & 69 & 73 & $6 \mathrm{f}$ & $6 \mathrm{~d}$ & 69 & 73 & $6 f$ & 32 & 61 & 76 & 63 & 31 & $6 \mathrm{~d}$ & 70 & 34 & 31 & isomiso2avclmp 41 \\
\hline 00000020 & 00 & 00 & 18 & $8 a$ & $6 \mathrm{~d}$ & $6 f$ & $6 f$ & 76 & 00 & 00 & 00 & $6 \mathrm{c}$ & $6 \mathrm{~d}$ & 76 & 68 & 64 & ... S̆moov... lmohd \\
\hline 00000030 & 00 & 00 & 00 & 00 & d 6 & $8 \mathrm{e}$ & 07 & d 9 & d6 & $8 \mathrm{e}$ & 07 & d 9 & 00 & 00 & 03 & e8 & …öžżüöž. Ù...è \\
\hline \multicolumn{18}{|c|}{ (a) file asli } \\
\hline & 00 & 01 & 02 & 03 & 04 & 05 & 06 & 07 & 08 & 09 & $0 a$ & $\mathrm{Ob}$ & $0 \mathrm{c}$ & od & De & of & \\
\hline 00000000 & 00 & 00 & 00 & 20 & 66 & 74 & 79 & 70 & 69 & 73 & $6 \mathrm{f}$ & $6 \mathrm{~d}$ & 00 & 00 & 02 & 00 & ... ftypisom.... \\
\hline 00000010 & 69 & 73 & $6 \mathrm{f}$ & $6 \mathrm{~d}$ & 69 & 73 & $6 f$ & 32 & 61 & 76 & 63 & 31 & $6 \mathrm{~d}$ & 70 & 34 & 31 & isomiso2avclmp 41 \\
\hline 00000020 & 00 & 00 & 00 & 18 & 62 & 65 & 61 & $6 \mathrm{~d}$ & 01 & 00 & 00 & 00 & 01 & 00 & 00 & 00 & ....beam....... \\
\hline 00000030 & 00 & 00 & 00 & 00 & 07 & 00 & 00 & 00 & 00 & 00 & 18 & $8 \mathrm{a}$ & $6 \mathrm{~d}$ & $6 \mathrm{f}$ & $6 \mathrm{f}$ & 76 & $\ldots \ldots \ldots$ s̆moov \\
\hline
\end{tabular}

(b) file sharing

Gambar 6. Perubahan Raw Header Hex Dump File Mp4 Di WhatsApp dengan Major Brand MP4 Base Media v1 [ISO 14496-12:2003]

Perubahan yang menjadi karakteristik utama untuk file gambar juga sama seperti file video terletak pada nilai raw header hex dump, karena hampir keseluruhan metadata mengalami perubahan nilai dan penghapusan nilai. Perubahan yang memiliki nilai sama ketika file gambar diunduh melalui WhatsApp terletak pada raw header urutan 21 bytes awal (0x00000000 - 0x00000014). Tabel 3 menampilkan 1 dari 82 jenis metadata yang menjadi karakteristik perubahan metadata yang diuji pada file sampel sebanyak 5 kali. 
Tabel 3. Karakteristik Perubahan Metadata File Sharing Jpg via Whatsapp

\begin{tabular}{|c|l|l|l|}
\hline No & \multicolumn{1}{|c|}{ Nama Metadata } & \multicolumn{1}{|c|}{ Nilai Metadata file Asli } & \multicolumn{1}{|c|}{ Nilai Metadata file Sharing } \\
\hline 1. & Raw Header Hex & ff d8 ff e1 45 6d 45 78 6966 00 00 & ff d8 ff e0 00 10 4a 46 49 4600 01 \\
Dump & 4949 2a 00 08 00 00 00 0b & $0100000100010000 \mathrm{ff}$ \\
\hline
\end{tabular}

\begin{tabular}{|c|c|c|c|c|c|c|c|c|c|c|c|c|c|c|c|c|c|}
\hline & 00 & 01 & 02 & 03 & 04 & 05 & 06 & 07 & 08 & 09 & $0 \mathrm{a}$ & $\mathrm{Ob}$ & $0 \mathrm{c}$ & $0 \mathrm{~d}$ & De & of & \\
\hline 00000000 & ff & d8 & ff & el & 45 & $6 \mathrm{~d}$ & 45 & 78 & 69 & 66 & 00 & 00 & 49 & 49 & $2 a$ & 00 & Y̛⿴囗̈áEmExif..II*. \\
\hline 00000010 & 08 & 00 & 00 & 00 & $\mathrm{ob}$ & 00 & of & 01 & 02 & 00 & 05 & 00 & 00 & 00 & 92 & 00 & $\ldots \ldots \ldots \ldots \ldots{ }^{\prime}$ \\
\hline 00000020 & 00 & 00 & 10 & 01 & 02 & 00 & 06 & 00 & 00 & 00 & 98 & 00 & 00 & 00 & 12 & 01 & $\ldots \ldots \ldots{ }^{*}$. \\
\hline 00000030 & 03 & 00 & 01 & 00 & 00 & 00 & 06 & 00 & 00 & 00 & la & 01 & 05 & 00 & 01 & 00 & \\
\hline
\end{tabular}

(a) file asli

\begin{tabular}{|c|c|c|c|c|c|c|c|c|c|c|c|c|c|c|c|c|c|}
\hline & 00 & 01 & 02 & 03 & 04 & 05 & 06 & 07 & 08 & 09 & $0 \mathrm{a}$ & $\mathrm{Ob}$ & $0 \mathrm{c}$ & $0 d$ & oe & of & \\
\hline 00000000 & ff & d8 & ff & e0 & 00 & 10 & $4 a$ & 46 & 49 & 46 & 00 & 01 & 01 & 00 & 00 & 01 & ŸGप̈à..JFIF...... \\
\hline 00000010 & 00 & 01 & 00 & 00 & ff & $\mathrm{db}$ & 00 & 43 & 00 & 03 & 02 & 02 & 02 & 02 & 02 & 03 & 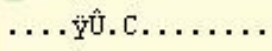 \\
\hline 00000020 & 02 & 02 & 02 & 03 & 03 & 03 & 03 & 04 & 06 & 04 & 04 & 04 & 04 & 04 & 08 & 06 & $\cdots$ \\
\hline 00000030 & 06 & 05 & 06 & 09 & 08 & $0 \mathrm{a}$ & $0 \mathrm{a}$ & 09 & 08 & 09 & 09 & $0 \mathrm{a}$ & $0 \mathrm{c}$ & of & $0 \mathrm{c}$ & $0 \mathrm{a}$ & $\ldots \ldots \ldots \ldots \ldots \ldots$ \\
\hline
\end{tabular}

(b) file sharing

Gambar 7. Perubahan Raw Header Hex Dump File Jpg Di WhatsApp

Untuk file audio dan file dokumen tidak terjadi perubahan metadata apapun dibuktikan dengan nilai metadata checksum meliputi nilai MD5 dan SHA-256 yang tidak ada perubahan sama sekali. Lihat pada Tabel 4, Tabel 5 dan Tabel 6. Metadata checksum akan berubah apabila ada perubahan di dalam sebuah file walaupun perubahan hanya 1 bit dari bagian file itu.

Tabel 4. Metadata Checksum File Sharing Mp3 via Whatsapp

\begin{tabular}{|c|l|l|l|}
\hline No & Nama Metadata & \multicolumn{1}{|c|}{ Nilai Metadata file Asli } & \multicolumn{1}{|c|}{ Nilai Metadata file Sharing } \\
\hline 1. & MD5 & $\begin{array}{l}\text { 9db882865822dbaca208770c1f0b0 } \\
\text { eb5 }\end{array}$ & $\begin{array}{l}\text { 9db882865822dbaca208770c1f0b0 } \\
\text { eb5 }\end{array}$ \\
\hline 2. & SHA-256 & $\begin{array}{l}\text { 7f11d0e80b0f9d3df33b86c9d241cb } \\
22729 \mathrm{~d} 894 \mathrm{~d} 1 \mathrm{~b} 62 \mathrm{~b} 802 \mathrm{f} 975217 \mathrm{c} 94 \mathrm{ff} \\
\mathrm{b} 804\end{array}$ & $\begin{array}{l}\text { 7f11d0e80b0f9d3df33b86c9d241cb } \\
\text { 22729b894a1b62b802f975217c94ff } \\
\text { b804 }\end{array}$ \\
\hline
\end{tabular}

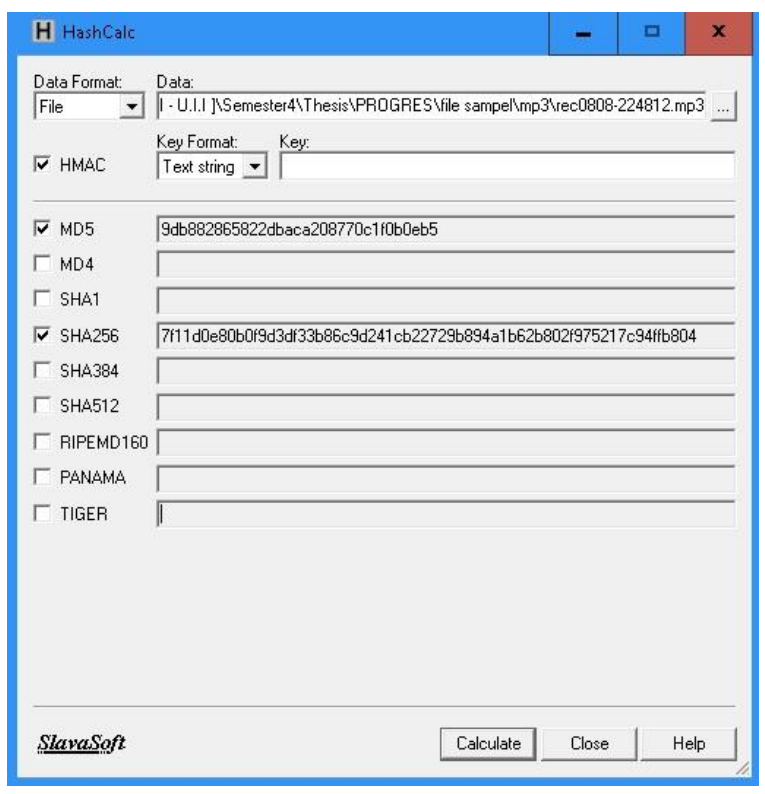

(a) file asli

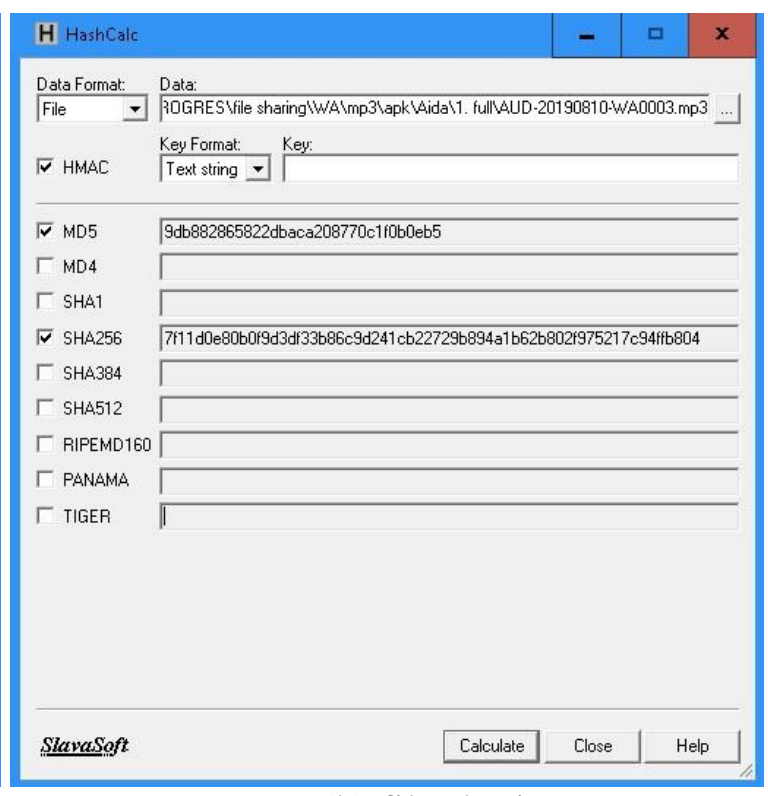

(b) file sharing

Gambar 8. Perubahan Metadata Checksum File Mp3 Di WhatsApp 
Tabel 5. Metadata Checksum File Sharing Pdf via Whatsapp

\begin{tabular}{|c|l|l|l|}
\hline No & \multicolumn{1}{|c|}{ Nama Metadata } & \multicolumn{1}{|c|}{ Nilai Metadata file Asli } & \multicolumn{1}{|c|}{ Nilai Metadata file Sharing } \\
\hline 1. & MD5 & $\begin{array}{l}8 \mathrm{ceba} 0546 \mathrm{~d} 90295 \mathrm{a} 0 \mathrm{c} 8 \mathrm{~b} 8749771 \mathrm{ee} \\
938\end{array}$ & $\begin{array}{l}8 \mathrm{c} \text {-ba0546d90295a0c8b8749771ee } \\
938\end{array}$ \\
\hline & & $\begin{array}{l}\mathrm{d} 0831772 \mathrm{c} 1 \mathrm{~b} 96 \mathrm{c} 74087672 \mathrm{~b} 5 \mathrm{~b} 69 \mathrm{c} 8 \\
\mathrm{a} 5 \mathrm{a} 5 \mathrm{~d} 3 \mathrm{a} 78 \mathrm{~d} 49236292 \mathrm{a} 1 \mathrm{a} 9 \mathrm{~d} 25586 \mathrm{c}\end{array}$ & $\begin{array}{l}\text { d0831772c1b96c74087672b5b69c8 } \\
\text { a5a5d3a78d49236292a1a9d25586c } \\
255559\end{array}$ \\
2. & SHA-256 & 255559 & \\
\hline
\end{tabular}

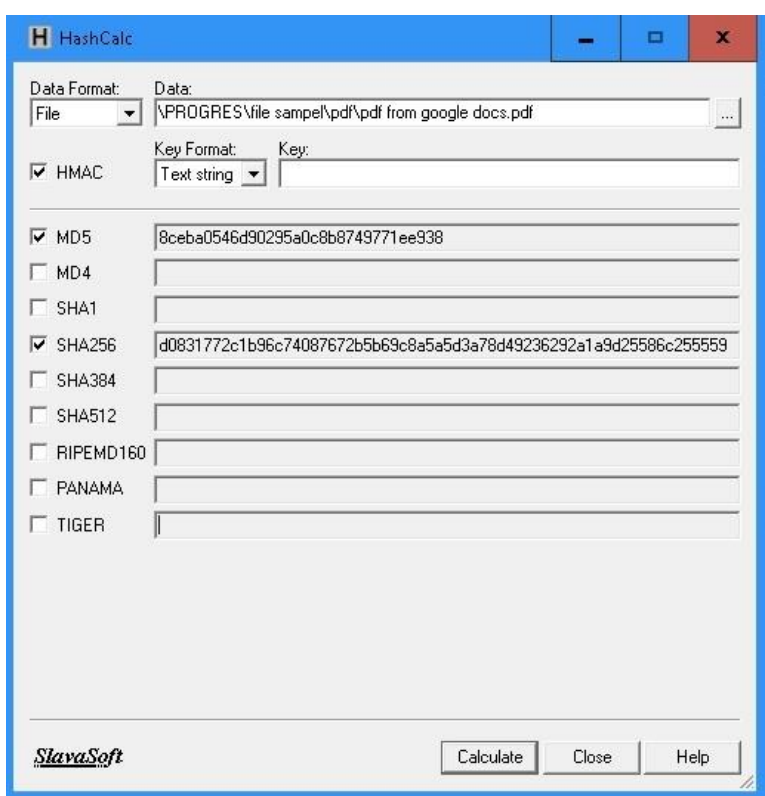

(a) file asli

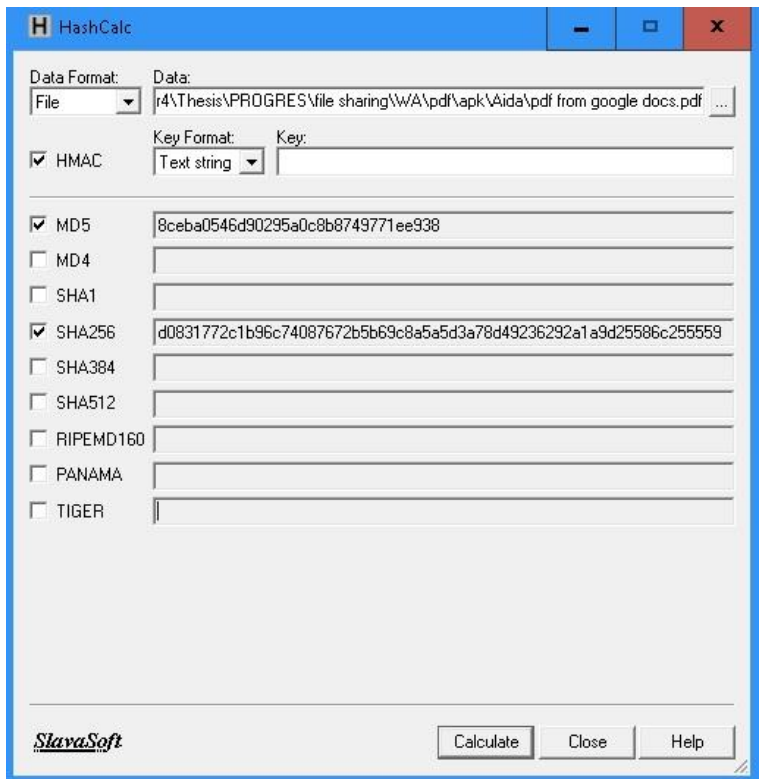

(b) file sharing Gambar 9. Perubahan Metadata Checksum File Pdf Di WhatsApp

Tabel 6. Metadata Checksum File Sharing Docx via Whatsapp

\begin{tabular}{|c|l|l|l|}
\hline No & Nama Metadata & \multicolumn{1}{|c|}{ Nilai Metadata file Asli } & \multicolumn{1}{|c|}{ Nilai Metadata file Sharing } \\
\hline 1. & MD5 & $\begin{array}{l}\text { 69c90f73bd4fb3a4e1089cbec30db3 } \\
\text { 0d }\end{array}$ & $\begin{array}{l}\text { 69c90f73bd4fb3a4e1089cbec30db3 } \\
\text { 0d }\end{array}$ \\
\hline 2. & SHA-256 & $\begin{array}{l}\text { 0f67d83daaf7283729dc6e8ecc9cc9 } \\
\text { c2903a4aed10753d88eec12d50b0b } \\
\text { ac4ce }\end{array}$ & $\begin{array}{l}\text { 0f67d83daaf7283729dc6e8ecc9cc9 } \\
\text { c2903a4aed10753d88eec12d50b0b } \\
\text { ac4ce }\end{array}$ \\
\hline
\end{tabular}




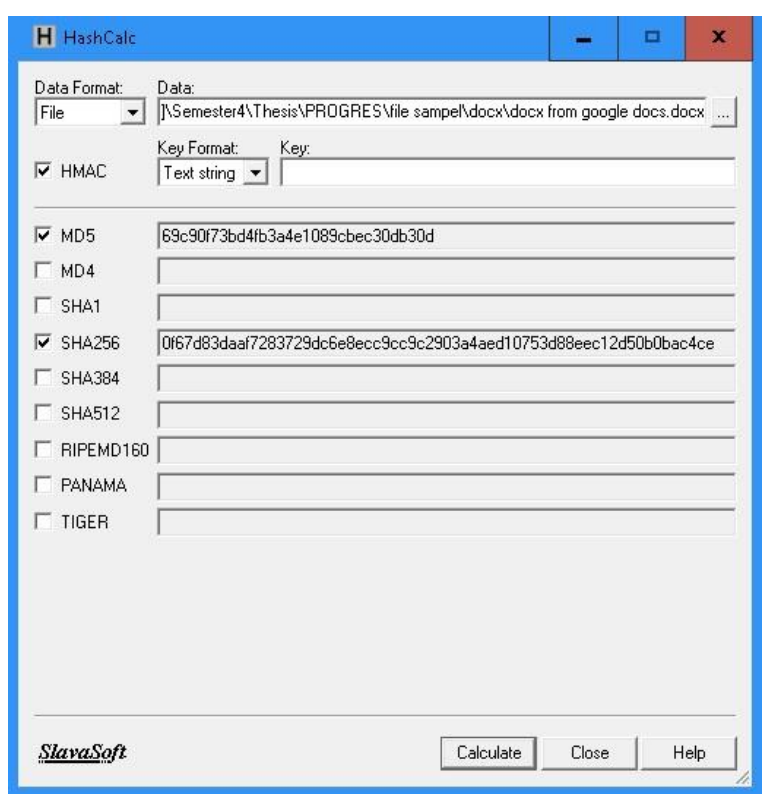

(a) file asli

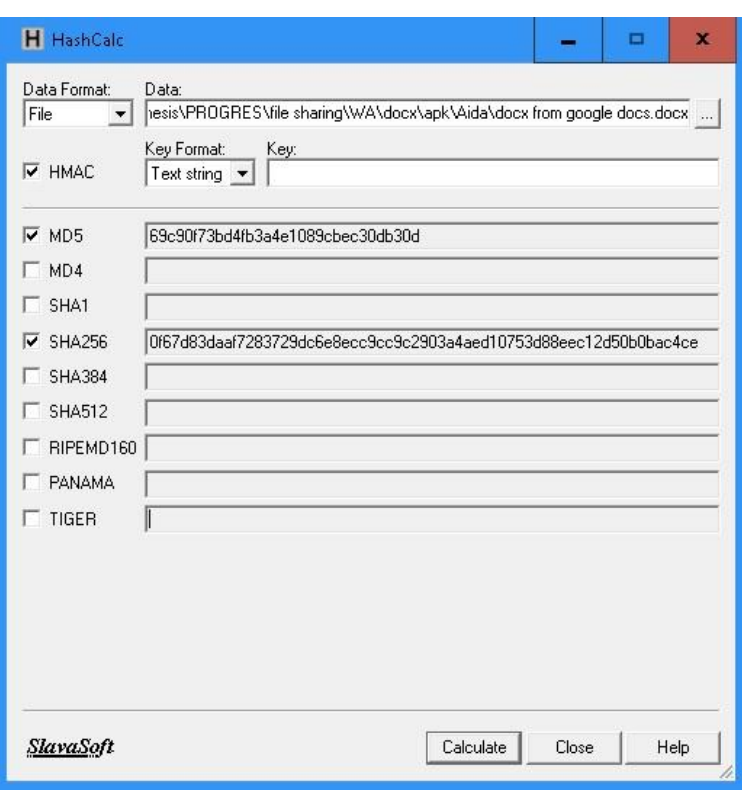

(b) file sharing

Gambar 10. Perubahan Metadata Checksum File Docx Di WhatsApp

\section{Media Sosial FaceBook}

Facebook dapat digunakan untuk berbagi file video dan gambar pada bagian postingan beranda. Facebook dalam penelitian ini bukan FB Messenger, karena FB Messenger merupakan aplikasi yang berbeda dengan Facebook pada umumnya. Lihat kembali Gambar 1. Platform media sosial yang paling aktif di Indonesia.

Perubahan yang menjadi karakteristik utama untuk file video terletak pada metadata bernama Compatiblebrands Encoder yang selalu bernilai : Lavf58.20.100 dan metadata tambahan bernama Format Title yang nilainya diawali dengan : 10212141xxxxxxxxx. Karena sebagain besar perubahan metadatanya hampir sama dengan perubahan metadata pada media sosial Instagram. Tabel 7 menampilkan 2 dari 84 jenis metadata yang menjadi karakteristik perubahan metadata yang diuji pada file sampel sebanyak 5 kali.

Tabel 7. Karakteristik Perubahan Metadata File Sharing Mp4 via Facebook

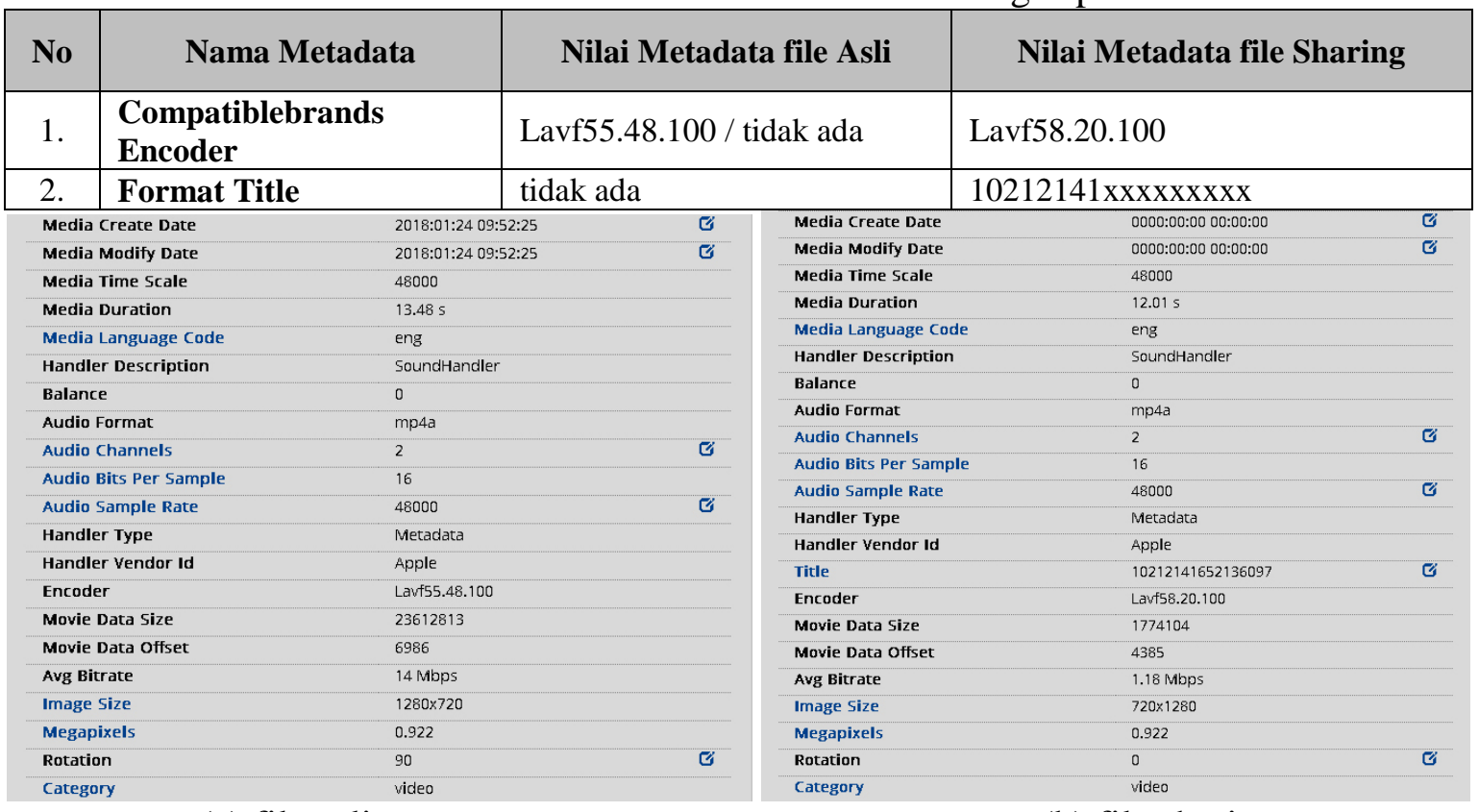

(a) file asli

(b) file sharing

Gambar 11. Perubahan Metadata File Mp4 Di Facebook 
Untuk perubahan file gambar yang telah dibagikan lewat Facebook, karakteristik utama terletak pada metadata tambahan pada file sharing. Ada banyak penambahan metadata yang terjadi. Metadata tambahan disini adalah metadata yang sebelumnya tidak ada, menjadi ada setelah file tersebut diunduh dari Facebook.

Terdapat tambahan kelompok metadata Profile yakni : Profile Cmm type, Profile Version, Profile Class, Profile Connection Space, Profile Date Time, Profile File Signature, Profile Id, Profile Description, Profile Copyright, Profile Creator.

Terdapat tambahan kelompok metadata Measurement yakni : Measurement Observer, Measurement Backing, Measurement Geometry, Measurement Flare, Measurement Illuminant.

Terdapat tambahan metadata : Primary Platform, Cmm Flags, Device Attributes, Rendering Intent, Connection Space Illuminant, Blue Matrix Column, Blue Trc, Device Model Desc, Green Matrix Column, Green Trc, Luminance, Media Black Point, Red Matrix Column, Red Trc, Technology, Viewing Cond Desc, Media White Point, Chromatic Adaption, Current Iptc Digest, Original Transmission Reference.

Terdapat perubahan metadata Encoding Process dengan nilai : Progressive DCT,

\section{Huffman coding.}

\begin{tabular}{|l|l|}
\hline Make \\
\hline Model \\
\hline Orientation \\
\hline X Resolution \\
\hline Y Resolution \\
\hline Resolution Unit \\
\hline Software \\
\hline Modify Date \\
\hline Y Cb Cr Positioning \\
\hline Exposure Time \\
\hline F Number \\
\hline Iso \\
\hline Exif Version \\
\hline Date Time Original \\
\hline Create Date \\
\hline Components Configuration \\
\hline Shutter Speed Value \\
\hline Exposure Compensation \\
\hline Metering Mode \\
\hline Light Source \\
\hline Flash \\
\hline Focal Length \\
\hline Soft Skin Effect \\
\hline Face Info Offset \\
\hline Sony Date Time \\
\hline Sony Image Height \\
\hline Sony Image Width \\
\hline
\end{tabular}

(a) file asli

\begin{tabular}{l} 
Sony \\
D5503 \\
\hline Rotate $90 \mathrm{CW}$ \\
72 \\
\hline 72 \\
\hline inches \\
\hline 14.6.A.1.236_6_f1000010 \\
\hline $2019: 06: 21$ 18:49:53 \\
\hline Centered \\
\hline 1/16 \\
\hline 2 \\
\hline 3200 \\
\hline 220 \\
\hline $2019: 06: 21$ 18:49:53 \\
\hline $2019: 06: 21$ 18:49:53 \\
\hline Y, Cb, Cr, - \\
\hline 1/16 \\
\hline 0 \\
\hline Multi-segment \\
\hline Unknown \\
\hline Off, Did not fire \\
\hline 4.9 mm \\
\hline Unknown (65536) \\
\hline 94 \\
\hline $2019: 06: 21$ 18:49:53 \\
\hline 2160 \\
\hline 3840 \\
\hline
\end{tabular}

Gambar 12. Perubahan Metadata File Jpg Di Facebook

4. Media Sosial Instagram

Instagram dapat digunakan untuk berbagi file video dan gambar. Perubahan yang menjadi karakteristik utama pada file video Instagram terletak pada metadata bernama Compatiblebrands Encoder yang selalu bernilai : Lavf56.40.101. Selain itu metadata bernama Image Size yang selalu bernilai : 640x640 (setiap file video dari instagram selalu memiliki ukuran resolusi 640x640 pixel) dan metadata bernama Megapixels yang selalu bernilai : 0.41. Setiap file video yang diunduh melalui media sosial Instagram selalu memiliki metadata dengan nilai tersebut. Tabel 8 menampilkan 1 dari 84 jenis metadata yang menjadi karakteristik perubahan metadata yang diuji pada file sampel sebanyak 5 kali. 
Tabel 8. Karakteristik Perubahan Metadata File Sharing Mp4 via Instagram

\begin{tabular}{|c|l|l|l|}
\hline No & \multicolumn{1}{|c|}{ Nama Metadata } & \multicolumn{1}{|c|}{ Nilai Metadata file Asli } & \multicolumn{1}{|c|}{ Nilai Metadata file Sharing } \\
\hline 1. & $\begin{array}{l}\text { Compatiblebrands } \\
\text { Encoder }\end{array}$ & Lavf55.48.100/ tidak ada & Lavf56.40.101 \\
\hline 2. & Image Size & $1280 \times 720 / 1920 \times 1080$ & $640 \times 640 \mathrm{px}$ \\
\hline 3. & Megapixels & $0.922 / 2.1$ & 0.41 \\
\hline
\end{tabular}

\begin{tabular}{|l|}
\hline Media Create Date \\
\hline Media Modify Date \\
\hline Media Time Scale \\
\hline Media Duration \\
\hline Handler Type \\
\hline Handler Description \\
\hline Balance \\
\hline Audio Format \\
\hline Audio Channels \\
\hline Audio Bits Per Sample \\
\hline Audio Sample Rate \\
\hline Movie Data Size \\
\hline Movie Data Offset \\
\hline Avg Bitrate \\
\hline Image Size \\
\hline Megapixels \\
\hline Rotation \\
\hline Category \\
\hline
\end{tabular}

(a) file asli

\begin{tabular}{l}
\hline 2019:08:12 06:46:56 \\
\hline $2019: 08: 1206: 46: 56$ \\
\hline 48000 \\
\hline 20.425 \\
\hline Audio Track \\
\hline SoundHandle \\
\hline 0 \\
\hline mp4a \\
\hline 2 \\
\hline 16 \\
\hline 48000 \\
\hline 45055807 \\
\hline 810040 \\
\hline 17.6 Mbps \\
\hline $1920 \times 1080$ \\
\hline 2.1 \\
90 \\
\hline video \\
\hline
\end{tabular}

\begin{tabular}{|l|l|}
\hline & Media Create Date \\
\hline & Media Modify Date \\
\hline Media Time Scale \\
\hline Media Duration \\
\hline Media Language Code \\
\hline & Handler Description \\
\hline Balance \\
\hline Audio Format \\
\hline Audio Channels \\
\hline Audio Bits Per Sample \\
\hline Audio Sample Rate \\
\hline Handler Type \\
\hline Handler Vendor Id \\
\hline Encoder \\
\hline Movie Data Size \\
\hline Movie Data Offset \\
\hline Avg Bitrate \\
\hline Image Size \\
\hline Megapixels \\
\hline Rotation \\
\hline Category \\
\hline
\end{tabular}

\begin{tabular}{l}
\hline 0000:00:00 00:00:00 \\
\hline 0000:00:00 00:00:00 \\
\hline 48000 \\
\hline 20.50 s \\
\hline und \\
\hline SoundHandler \\
\hline 0 \\
\hline mp4a \\
\hline 2 \\
\hline 16 \\
\hline 48000 \\
\hline Metadata \\
\hline Apple \\
\hline Lavt56.40.101 \\
\hline 1603309 \\
\hline 23551 \\
\hline 626 kbps \\
\hline $640 \times 640$ \\
\hline 0.41 \\
\hline 0 \\
\hline video \\
\hline
\end{tabular}

(b) file sharing

Gambar 13. Perubahan Metadata File Mp4 Di Instagram

Untuk perubahan yang menjadi karakteristik utama pada file gambar Instagram terletak pada metadata Image Size yang selalu bernilai : 1080x1080 dengan Megapixels bernilai : 1.2. Selain itu dari nilai raw header hex dump. Tabel 9 menampilkan 3 dari 82 jenis metadata yang menjadi karakteristik perubahan metadata yang diuji pada file sampel sebanyak 5 kali.

Tabel 9. Karakteristik Perubahan Metadata File Sharing Jpg via Instagram

\begin{tabular}{|c|c|c|c|}
\hline No & Nama Metadata & Nilai Metadata file Asli & Nilai Metadata file Sharing \\
\hline 1. & Image Size & $2840 \times 2160 / 640 \times 480$ & $1080 \mathrm{x} 1080 \mathrm{px}$ \\
\hline 2. & Megapixels & $8.3 / 0.307$ & 1.2 \\
\hline 3. & Raw Header Hex Dump & $\begin{array}{l}\text { ff d8 ff e1 } 456 \mathrm{~d} 45786966 \\
000049492 \mathrm{a} 00 \\
080000000 \mathrm{~b} 00 \text { of } 010200 \\
050000009200 \\
00001001020006000000 \\
980000001201 \\
03000100000006000000 \\
1 \mathrm{a} 0105000100\end{array}$ & 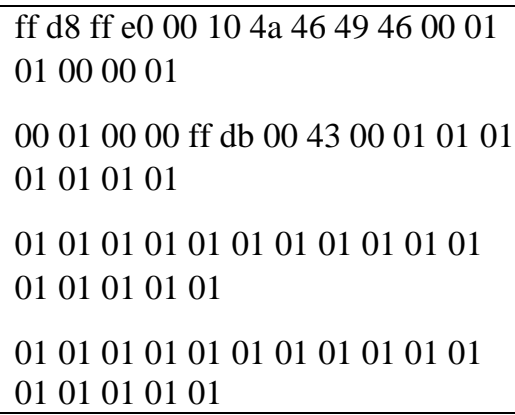 \\
\hline
\end{tabular}

\begin{tabular}{lll|}
\hline Image Size & $3840 \times 2160$ \\
\hline Megapixels & 8.3 & \\
\hline Shutter Speed & $1 / 16$ & \\
\hline Sub Sec Create Date & $2019: 06: 21$ 18:49:53.225900 & \\
\hline Sub Sec Date Time Original & $2019: 06: 21$ 18:49:53.225900 & \\
\hline Sub Sec Modify Date & $2019: 06: 21$ 18:49:53.225900 & \\
\hline Thumbnail Image & (Binary data 5301 bytes) & \\
\hline Focal Length35Efl & $4.9 \mathrm{~mm}$ & \\
\hline Light Value & 1 & \\
\hline Category & image \\
\hline
\end{tabular}

(a) file asli

\begin{tabular}{|ll|}
\hline Jfif Version & 1.01 \\
\hline Resolution Unit & None \\
\hline X Resolution & 1 \\
\hline Y Resolution & 1 \\
\hline Image Width & 1080 \\
\hline Image Height & 1080 \\
\hline Encoding Process & Baseline DCT, Huffman coding \\
\hline Bits Per Sample & 8 \\
\hline Color Components & 3 \\
\hline Y Cb Cr Sub Sampling & YcbCr4:2:0 (22) \\
\hline Image Size & $1080 \times 1080$ \\
\hline Megapixels & 1.2 \\
\hline Category & image \\
\hline
\end{tabular}

(b) file sharing

Gambar 14. Perubahan Metadata File Jpg Di Instagram 


\begin{tabular}{|c|c|c|c|c|c|c|c|c|c|c|c|c|c|c|c|c|c|}
\hline & 00 & 01 & 02 & 03 & 04 & 05 & 06 & 07 & 08 & 09 & $0 \mathrm{a}$ & $\mathrm{ob}$ & $0 \mathrm{c}$ & $0 \mathrm{~d}$ & De & of & \\
\hline 00000000 & ff & d8 & ff & el & 45 & $6 \mathrm{~d}$ & 45 & 78 & 69 & 66 & 00 & 00 & 49 & 49 & $2 a$ & 00 & ŸGÿáEmExif..II*. \\
\hline 00000010 & 08 & 00 & 00 & 00 & $\mathrm{Ob}$ & 00 & of & 01 & 02 & 00 & 05 & 00 & 00 & 00 & 92 & 00 & $\ldots \ldots \ldots \ldots m^{\prime}$. \\
\hline 00000020 & 00 & 00 & 10 & 01 & 02 & 00 & 06 & 00 & 00 & 00 & 98 & 00 & 00 & 00 & 12 & 01 & $\ldots \ldots \ldots{ }^{n} \ldots$ \\
\hline \multicolumn{18}{|c|}{ (a) file asli } \\
\hline & 00 & 01 & 02 & 03 & 04 & 05 & 06 & 07 & 08 & 09 & $0 a$ & $\mathrm{Ob}$ & $0 \mathrm{c}$ & $0 \mathrm{~d}$ & De & of & \\
\hline 00000000 & ff & d8 & ff & e0 & 00 & 10 & $4 a$ & 46 & 49 & 46 & 00 & 01 & 01 & 00 & 00 & 01 & y̆dÿà. .JFIF...... \\
\hline 00000010 & 00 & 01 & 00 & 00 & ff & $\mathrm{db}$ & 00 & 43 & 00 & 01 & 01 & 01 & 01 & 01 & 01 & 01 & 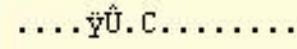 \\
\hline 00000020 & 01 & 01 & 01 & 01 & 01 & 01 & 01 & 01 & 01 & 01 & 01 & 01 & 01 & 01 & 01 & 01 & $\ldots \ldots \ldots \ldots \ldots$ \\
\hline 00000030 & 01 & 01 & 01 & 01 & 01 & 01 & 01 & 01 & 01 & 01 & 01 & 01 & 01 & 01 & 01 & 01 & $\ldots \ldots \ldots \ldots \ldots \ldots$ \\
\hline
\end{tabular}

(b) file sharing

Gambar 15. Perubahan Raw Header Hex Dump File Jpg Di Instagram

\section{KESIMPULAN DAN SARAN \\ 5.1 KESIMPULAN}

Metadata pada file yang telah dibagikan melalui media sosial mengalami banyak perubahan, penambahan dan penghapusan, khususnya pada file multimedia seperti gambar dan video. Untuk mengetahui karakteristik yang spesifik dapat dilihat pada perubahan metadata detail dan nilai hex dump bagian raw header. Metadata general seperti nama file dan ekstensi file mengalami perubahan yang tidak spesifik yang artinya tidak bisa digunakan untuk mengetahui sumber penyebaran file melalui media sosial karena nama file sifatnya yang mudah untuk dirubah (rename). Sedangkan metadata checksum seperti MD5 dan SHA256 dapat digunakan untuk mengetahui keaslian file yang telah dibagikan melalui media sosial.

Perubahan metadata secara spesifik dapat digunakan untuk mengenali atau mengetahui sumber penyebaran file yang telah dibagikan melalui media sosial. Semua file yang telah dibagikan melalui media sosial mengalami perubahan metadata, mulai dari penambahan dan penghapusan metadata, kecuali pada media sosial WhatsApp yang dibagikan melalui lampiran dokumen dan audio tidak terjadi perubahan nilai metadata, artinya file yang dibagikan melalui lampiran dokumen dan audio tersebut dapat dikatakan sebagai file asli dan dapat dijadikan sebagai barang bukti yang sah dalam persidangan.

Menentukan sumber media sosial yang digunakan untuk membagikan file digital dapat dilihat dari nilai metadata hasil file sharing. File mp4 dari youtube dapat dilihat pada metadata Media Time Scale, Handler Description, Sample Rate dan Rotation. File mp4 dan jpg dari whatsapp pada metadata Raw Header. Untuk file mp3, pdf dan docx dari whatsapp tidak terjadi perubahan (masih file asli). File mp4 dari facebook dapat dilihat pada metadata Encoder dan Format Title, untuk file jpg dari facebook ada banyak penambahan nilai metadata contohnya kelompok metadata Profile dan Measurement. File mp4 dari instagram dapat dilihat pada metadata Encoder, Image Size dan Megapixels, untuk file jpg dari instagram dapat dilihat pada metadata Image Size, Megapixels dan Raw Header.

\subsection{SARAN}

Penelitian ini hanya menggunakan lima file sampel untuk setiap jenis ekstensi yakni MP4, JPG, MP3, DOCX dan PDF. Pada penelitian selanjutnya, untuk meningkatkan informasi perubahan karakteristik metadata yang terjadi dapat ditambahkan jumlah file sampelnya, ditambahkan variasi jenis perangkat atau aplikasi yang digunakan untuk membuat file sampelnya dan manipulasi file sampelnya seperti membagikan ulang (re- 
post) file yang telah diunduh pada media sosial yang sama maupun media sosial yang berbeda.

Penelitian ini hanya menggunakan empat media sosial untuk melihat perubahan metadata pada file yang telah dibagikan. Pada penelitian selanjutnya, untuk mengetahui lebih banyak karakteristik perubahan metadata yang telah dibagikan melalui media sosial dapat ditambahkan media sosial yang lainnya, barang kali ada karakteristik yang sama dari media sosial satu dengan yang lain.

\section{UCAPAN TERIMA KASIH}

Penulis mengucapkan banyak terima kasih kepada para reviewer yang telah memberikan koreksi dan masukan untuk perbaikan sampai terpublikasinya naskah ini.

\section{DAFTAR PUSTAKA}

Alanazi, F., \& Jones, A. (2016). The Value of Metadata in Digital Forensics. Proceedings 2015 European Intelligence and Security Informatics Conference, EISIC 2015, 8(2011), 182. https://doi.org/10.1109/EISIC.2015.26

Hootsuite. (2020). Hootsuite (We are Social): Indonesian Digital Report 2020. Retrieved July 24, 2020, from https://datareportal.com/reports/digital-2020-indonesia

Khatri, Y. (2019). Investigating spotlight internals to extract metadata. Digital Investigation, 28, 96-103. https://doi.org/10.1016/j.diin.2019.01.005

Kumar, P. R., Srikanth, C., \& Sailaja, K. L. (2016). Location Identification of the Individual based on Image Metadata. Procedia Computer Science, 85(Cms), 451-454. https://doi.org/10.1016/j.procs.2016.05.191

Putra, A. I., Umar, R., \& Fadlil, A. (2018). Analisis forensik deteksi keaslian metadata video menggunakan exiftool. Seminar Nasional Informatika (SemnasIF), 2018, 2125.

Riley, J. (NISO). (2017). Understanding Metadata - What Is Metadata? Washington DC, United States: National Information Standards Organization (http://www. niso. org/publications/press/UnderstandingMetadata. pdf).

Spore, A. (2016). Using Metadata in Litigation. Proquest.

Subli, M., Sugiantoro, B., \& Prayudi, Y. (2017). Metadata forensik untuk mendukung proses investigasi digital. Jurnal Ilmiah DASI (Data Manajemen Dan Teknologi Informasi), 18, 44-50.

Zaenudin, Sugiantoro, B., \& Prayudi, Y. (2018). Correlation Analysis Of Forensic Metadata For Digital Evidence. International Journal of Computer Science and Information Security (IJCSIS), 16(3), 85-89. 